\title{
Production of Lysine by Pyruvate Kinase Mutants of Brevibacterium flavum
}

\author{
Hachiro Ozaki and Isamu SHIIO \\ Central Research Laboratories, Ajinomoto Co., Inc., \\ Kawasaki-ku, Kawasaki, Kanagawa 210, Japan \\ Received January 6, 1983
}

\begin{abstract}
A mutant, No. 1-231, resistant to $S$-(2-aminoethyl)-L-cysteine (AEC) plus threonine which was previously derived from a low citrate synthase mutant (No. 15-8) of Brevibacterium flavum, produced $41 \mathrm{~g} /$ liter of lysine (as $\mathrm{HCl}$ salt, $41 \%$ yield) and showed pyruvate kinase and homoserine dehydrogenase activities of about $1 / 10$ and $1 / 20$ as much as those of No. 15-8, respectively, but its aspartokinase was still normally sensitive to the feedback inhibition by lysine plus threonine. Another AEC-resistant mutant, No. 2-190, from No. 15-8 showed aspartokinase insensitive to the feedback inhibition without any change in pyruvate kinase and homoserine dehydrogenase activities. In addition, both the two AEC-resistant mutants and parent No. 15-8 showed partial desensitization of phosphoenolpyruvate carboxylase to the feedback inhibition by L-aspartic acid.

$\beta$-Fluoropyruvic acid-sensitive mutants No. 22 and No. 2-11 were derived from No. 1-231. These sensitive strains produced $51 \mathrm{~g} /$ liter of lysine ( $51 \%$ yield) and were found to be completely defective in homoserine dehydrogenase activity.

It was concluded from the results that depression of pyruvate kinase activity leads to an increase in lysine production.
\end{abstract}

It was reported in the previous paper ${ }^{1)}$ that a citrate synthase (CS)-lacking glutamate auxotroph, No. 214, derived from Brevibacterium flavum No. 2247 and a glutamate-nonrequiring-low CS-revertant, No. 15-8, from No. 214 produced 6.6 and $10.5 \mathrm{~g} /$ liter of $\mathrm{L}-$ aspartic acid, respectively, and that an AECresistant mutant, No. 1-231, from No. 15-8 produced much more L-lysine than an AECresistant mutant derived directly from No. 2247. On the other hand, Tosaka et al. have reported that a $\beta$-fluoropyruvate (FP)-sensitive mutant of Brevibacterium lactofermentum shows pyruvate dehydrogenase activity of $27 \%$ as much as that of the parent strain and a higher yield of lysine. ${ }^{2)}$ Therefore, in this study, FP-sensitive mutants were derived from No. 1-231. Among them, mutants showing higher yields of lysine were obtained. Moreover, in order to clarify the factors causing the increase of lysine production, activity levels and sensitivities to the feedback inhibition of various enzymes related to biosynthesis of the amino acids were investigated.

\section{MATERIALS AND METHODS}

Chemicals. Sodium $\beta$-fluoropyruvate and 2 ( $p$-iodophenyl)-3-p-nitrophenyl-5-phenyl-tetrazolium chloride (INT) were purchased from Sigma, and phenazine methosulfate was from Tokyo Kasei Chem. Co. All other chemicals used were the same as reported in the previous papers. ${ }^{1,3)}$

Bacterial strains and culture media. Brevibacterium flavum No. 2247 (ATCC 14067) (wild strain), CS defective glutamate auxotroph No. $214^{3}$ derived from No. 2247, prototrophic revertant No. $15-8^{1)}$ derived from No. 214-1, lysine-producing AEC-resistant FAl-30,4) homoserine auxotroph $\mathrm{H} 1013^{5)}$ and methionine-sensitive strain S-20 $0^{6}$ derived from No. 2247, AEC-resistant strain No. 1-231, ${ }^{1)} 2-190,{ }^{1)}$ and methionine-sensitive

Abbreviations: PK, pyruvate kinase; PC, phosphoenolpyruvate carboxylase; PD, pyruvate dehydrogenase; CS, citrate synthase; AK, aspartokinase; HD homoserine dehydrogenase; AEC, $S$-(2-aminoethyl)-L-cysteine; FP, $\beta$-fluoropyruvate; INT, 3-p-nitrophenyl-5-phenyltetrazolium chloride. 
strain No. 2-396 (although it was formerly isolated as an AEC-resistant strain, reexamination indicated that it was not AEC-resistant but methionine-sensitive) derived from No. 15-8 were used. Medium 33 was composed of $100 \mathrm{~g}$ of glucose, $60 \mathrm{~g}$ of $\left(\mathrm{NH}_{4}\right)_{2} \mathrm{SO}_{4}, 1 \mathrm{~g}$ of $\mathrm{KH}_{2} \mathrm{PO}_{4}, 0.4 \mathrm{~g}$ of $\mathrm{MgSO}_{4} \cdot 7 \mathrm{H}_{2} \mathrm{O}, 10 \mathrm{mg}$ of $\mathrm{FeSO}_{4}$. $7 \mathrm{H}_{2} \mathrm{O}, 8 \mathrm{mg}$ of $\mathrm{MnSO}_{4} \cdot 4 \mathrm{H}_{2} \mathrm{O}, 300 \mu \mathrm{g}$ of $d$-biotin, $200 \mu \mathrm{g}$ of thiamine $\cdot \mathrm{HCl}, 2 \mathrm{ml}$ of Mieki (soybean-meal acid hydrolysate), $1 \mathrm{~g}$ of Casamino acids and $50 \mathrm{~g}$ of $\mathrm{CaCO}_{3}$ (separately sterilized) in a total volume of 1 liter, $\mathrm{pH}$ 7.0, and sterilized at $110^{\circ} \mathrm{C}$ for $10 \mathrm{~min}$. Compositions of medium 1 , medium 7 , medium 9 , medium 10 and medium 13 were reported in the previous paper. ${ }^{3)}$

Derivation of fluoropyruvate-sensitive mutants. Strain No. 1-231 was cultured for $16 \mathrm{hr}$ in medium 7 (without agar) supplemented with $10 \mathrm{~g}$ of monosodium glutamate per liter, and the cells harvested by centrifugation were washed twice with $0.1 \mathrm{M}$ sodium phosphate buffer, pH 7.0. The cells were treated with $1000 \mu \mathrm{g} / \mathrm{ml}$ of $N$ methyl- $N^{\prime}$-nitrosoguanidine at $30^{\circ} \mathrm{C}$ for $15 \mathrm{~min}$, washed again twice with the buffer and suspended in the buffer. Diluted cell suspension (about $2 \times 10^{3} / \mathrm{ml}$ ) was spread on medium 1 supplemented with $2 \mathrm{~g} /$ liter of sodium acetate and $20 \mathrm{~g} /$ liter of agar, and incubated at $30^{\circ} \mathrm{C}$ for 3 days. The colonies on the medium were replicated on medium 10 (minimum glucose medium) and medium 10 supplemented with $5 \mu \mathrm{g} / \mathrm{ml}$ of $\beta$-fluoropyruvate. After $24 \mathrm{hr}$ incubation at $30^{\circ} \mathrm{C}$, colonies which grew on the former but not on the latter were picked up and further investigated for the sensitivity to $\beta$-fluoropyruvate.

Lysine productivities of the bacterial strains were determined as described previously, ${ }^{1)}$ but using medium 33. Assay methods for lysine, ${ }^{1)}$ aspartic acid ${ }^{3)}$ and alanine $^{3)}$ were described previously. Valine was assayed by the bioassay method using Leuconostoc mesenteroides ATCC 8042.

Enzyme preparation. B. flavum or mutants were aerobically cultured at $30^{\circ} \mathrm{C}$ for $41 \mathrm{hr}$ in 500 -ml flasks containing $20 \mathrm{ml}$ of medium 33 supplemented with $5 \mathrm{~g} /$ liter of yeast extract. Crude enzyme extracts except for aspartokinase (AK) were prepared by sonic disruption of cells washed with $0.2 \% \mathrm{KCl}$ in $0.1 \mathrm{M} \mathrm{N}$-tris (hydroxymethyl)methyl-2-aminoethane sulfonic acid (TES)$\mathrm{NaOH}$ buffer, $\mathrm{pH} 7.5$, containing $30 \%$ glycerol and $5 \mathrm{mM} \mathrm{MgCl}_{2}$ (buffer A). Cell debris was removed by centrifugation at $30,000 \times g$ for $30 \mathrm{~min}$ at $0^{\circ} \mathrm{C}$. The supernatant was gel-filtered through a Sephadex G-50 column using buffer $\mathrm{A}$.

Crude AK was prepared by sonic disruption of cells and gel-filtration using $0.05 \mathrm{M}$ potassium phosphate buffer, $\mathrm{pH} 7.0$, containing $0.01 \mathrm{M} \mathrm{MgSO}_{4}$ and $0.8 \mathrm{M}$ ammonium sulfate.

Enzyme assay. Enzyme activities other than that of $\mathrm{AK}$ were determined by measuring the initial rates of the reactions with a Gilford 2600 recording spectrophotometer at room temperature $\left(20\right.$ to $\left.23^{\circ} \mathrm{C}\right)$, after the reactions had been started by the addition of the enzyme. Pyruvate dehydrogenase (PD) was assayed by the same method of Hinman and Blass ${ }^{8)}$ except that dithiothreitol (DTT) was omitted from the reaction mixture, because a high blank value was observed in the presence of DTT. The reaction mixture was composed of $0.05 \mathrm{M}$ potassium phosphate buffer, $\mathrm{pH} 7.8,1 \mathrm{mg} / \mathrm{ml}$ of bovine serum albumin, $1 \mathrm{~mm} \mathrm{MgCl}_{2}, 0.2 \mathrm{~mm}$ thiamine pyrophosphate, $0.1 \mathrm{~mm}$ Coenzyme A, $2.5 \mathrm{~mm}$ NAD, $5 \mathrm{~mm}$ sodium pyruvate, $6.5 \mu \mathrm{M}$ phenazine methosulfate, $0.6 \mathrm{~mm}$ INT and enzyme in a total volume of $1 \mathrm{ml}$.

Citrate synthase (CS), ${ }^{9)}$ pyruvate kinase $(\mathrm{PK}),{ }^{10)}$ phosphoenolpyruvate carboxylase (PC), ${ }^{10)}$ aspartokinase (AK), ${ }^{11}$ and homoserine dehydrogenase (HD) (reverse reaction) ${ }^{12)}$ were assayed by the same methods as previously reported.

Protein was determined by the method of Lowry et al. ${ }^{13)}$

\section{RESULTS}

\section{Derivation of $\beta$-fluoropyruvate-sensitive mu- tants from strain No. 1-231 and their lysine production}

$\beta$-Fluoropyruvate (FP)-sensitive mutants were derived from a low-CS-AEC-resistant mutant, No. $1-231^{1)}$ of B. flavum, which was derived in the previous study. In the first and second derivation experiments, 77 and 33 strains of FP-sensitive mutants were obtained, respectively. Lysine productivities of these mutants were determined. Most of the mutants were found to require yeast extract for their growth in medium 33 which has been used as the best medium for No. 1-231. Parent strain No. 1-231 produced $40 \mathrm{~g} /$ liter of L-lysine (as $\mathrm{HCl}$ salt) in this medium, but many of the strains showed higher lysine production than the parent as shown in Fig. 1. In experiments I and II, 7 and 6 strains produced more than $44 \mathrm{~g} /$ liter of lysine, respectively. Of them, two strains, No. 22 (Exp. I) and No. 2-11 (Exp. II), produced 55 and $52 \mathrm{~g} /$ liter of lysine $\cdot \mathrm{HCl}$, respectively.

When cultured in flasks containing medium 33 and various concentrations of yeast extract, both No. 22 and 2-11 accumulated $51 \mathrm{~g} /$ liter of lysine $\cdot \mathrm{HCl}$, as shown in Table I. On the other hand, parent strain No. 1-231 accumulated 


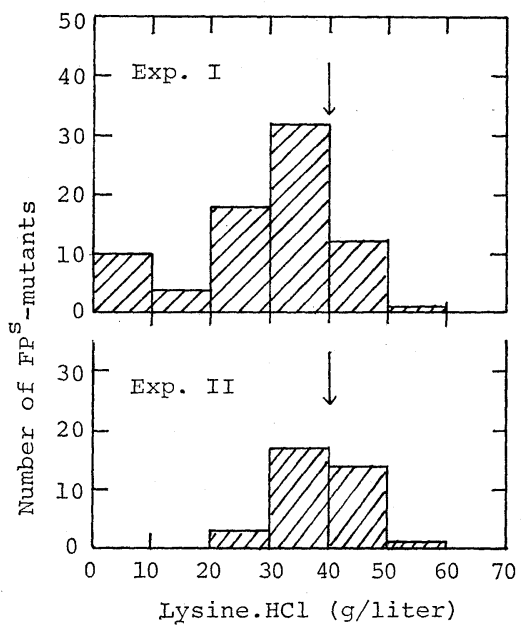

FIG. 1. Distribution of Lysine Productivity of Fluoropyruvate-sensitive Mutants from No. 1-231.

The lysine production of FP-sensitive mutants, 77 strains for Exp. I and 33 strains for Exp. II, was determined by cultivation in test tubes containing medium 33 supplemented with $5 \mathrm{~g} /$ liter of yeast extract. The arrows indicate the amount of lysine produced by parent strain No. 1-231.

$41 \mathrm{~g} /$ liter of lysine $\cdot \mathrm{HCl}$ in the absence of yeast extract, but the accumulation was slightly depressed by the addition of yeast extract. As the two strains were found to be homoserine auxotrophs, as described below, they were cultured in the presence of L-threonine and Lmethionine or L-homoserine instead of yeast extract: No. 22 and 2-11 accumulated $50 \mathrm{~g}$ and $46 \mathrm{~g} /$ liter of lysine $\cdot \mathrm{HCl}$, respectively, as shown in Table I.

Paper chromatography of the culture broth in Table I revealed that amino acids other than lysine were accumulated at the same time, and the amounts of the amino acids were determined by the bioassay method. The results are shown in Table II. Wild strain No. 2247 and AEC-resistant strain FA1-30 ${ }^{4}$ derived from No. 2247 hardly accumulated L-aspartic acid, but No. 15-8 and lysine-producing strains derived from No. 15-8 accumulated 0.1 $0.2 \mathrm{~g} /$ liter of L-aspartic acid. As for L-alanine, No. 2247 accumulated $0.5 \mathrm{~g} /$ liter, but FA1-30, No. 15-8 and the mutants from No. 15-8 did not at all. As for L-valine, No. 2247, FA1-30, 15-8 and 1-231 accumulated more than $0.24 \mathrm{~g} /$
Table I. Effects of Yeast Extract and Amino Acids on Production of Lysine IN $\beta$-FluoropyruVATE-SENSITIVE MUTANTS AND Their Parent

Strain No. 22, 2-11 and 1-231 were cultured in $500 \mathrm{ml}$ flasks containing $20 \mathrm{ml}$ of medium 33 supplemented with the indicated concentration of yeast extract, L-homoserine (Hse), or L-methionine plus Lthreonine.

\begin{tabular}{cccc}
\hline $\begin{array}{c}\text { Strain } \\
\text { No. }\end{array}$ & $\begin{array}{c}\text { Yeast extract } \\
(\mathrm{g} / \text { liter })\end{array}$ & $\begin{array}{c}\text { Growth } \\
\left(A_{562}\right)\end{array}$ & $\begin{array}{c}\text { Lysine } \\
\text { HCl } \\
(\mathrm{g} / \text { liter })\end{array}$ \\
\hline & 0 & 0.165 & 9 \\
& 1 & 0.275 & 15 \\
$22\left(\mathrm{FP}^{\mathrm{s}}\right)^{a}$ & 2 & 0.400 & 22 \\
& 5 & 0.550 & 36 \\
& 10 & 0.770 & 51 \\
& 0 plus & & \\
& $0.5 \mathrm{mg} / \mathrm{ml} \mathrm{Met}$ & 0.860 & 50 \\
& $0.5 \mathrm{mg} / \mathrm{ml} \mathrm{Thr}$ & & \\
\hline & 0 & 0.210 & 9 \\
& 1 & 0.320 & 23 \\
& 2 & 0.420 & 30 \\
& 5 & 0.700 & 51 \\
& 10 & 0.680 & 37 \\
& 0 plus & - & 46 \\
& $0.4 \mathrm{mg} / \mathrm{ml}$ Hse & & \\
\hline & 0 & 0.830 & 41 \\
& 1 & 0.930 & 35 \\
$1-231$ (parent) & 2 & 0.960 & 36 \\
& 5 & 1.060 & 37 \\
& 10 & 1.000 & 38 \\
\hline
\end{tabular}

$a \quad$ FPs,$\beta$-fluoropyruvate sensitive.

TABLE II. Byproducts of AMINo Acids BY VARIOUS LySINE-PRODUCING MUtANTS

All strains were cultured in medium 33 supplemented with $5 \mathrm{~g} /$ liter of yeast extract for $72 \mathrm{hr}$.

\begin{tabular}{llllll}
\hline \multirow{2}{*}{$\begin{array}{c}\text { Strain } \\
\text { No. }\end{array}$} & Property & \multicolumn{4}{c}{$\begin{array}{c}\text { Amino acids accumulated } \\
\text { (g/liter) }\end{array}$} \\
\cline { 3 - 6 } & & Asp & Ala & Val & Ile \\
\hline 2247 & Wild & 0.03 & 0.50 & 0.24 & \pm \\
FAl-30 & AEC $^{\text {r }}$ & 0.00 & 0.04 & 1.20 & + \\
$15-8$ & Glu $^{+}$ & 0.12 & 0.00 & 0.41 & \pm \\
$1-231$ & Glu $^{+}$AEC $^{r}$ & 0.20 & 0.00 & 0.50 & - \\
22 & Glu $^{+}$AEC $^{\text {r FPs }}$ & 0.20 & 0.00 & 0.04 & - \\
\hline
\end{tabular}

liter, but No. 22 accumulated it only slightly, $0.04 \mathrm{~g} /$ liter. As for isoleucine, No. 2247, FA130 and 15-8 showed a ninhydrin-reactive spot at the same $R f$ value as isoleucine on the paper- 
chromatogram, but No. 1-231 and No. 22 did not show the spot at all.

\section{Enzymatic change in $\beta$-fluoropyruvate-sensitive- improved lysine producers}

Tosaka et al. reported that a FP-sensitive strain showed lower PD-activity and produced more lysine than its parent. ${ }^{2)}$ PD activities of the FP sensitive-improved lysine producers, No. 22 and 2-11, obtained as above were determined and compared to parent strain No. 1231. Effects of components of the reaction mixture on PD activity were examined. As shown in Table III the activity was dependent on pyruvate, NAD, CoA, thiamine pyrophosphate and enzyme, indicating that the activity shows the over-all reaction of the PD-complex. Slightly higher activity in the absence of $\mathrm{MgCl}_{2}$ was attributable to the occurrence of high-concentration inhibition by $\mathrm{MgCl}_{2}$ in the complete system, since the enzyme solution itself contained $0.25 \mathrm{mM} \mathrm{MgCl}_{2}$ as the final concentration in the reaction mixture. The plot of PD activity against the amount of enzyme between 0.1 and $3 \mathrm{mg}$ as protein was approximately linear. As shown in Table IV, specific activities of PD of No. 22 and 2-11 were 11 and
TABle III. COFACTOR REQUIREMENTS FOR Pyruvate Dehydrogenase Activity

The reaction conditions were the same as described in Materials AND Methods. Crude enzyme $(2.8 \mathrm{mg}$ protein) of No. 2247 was added to the reaction mixtures. The complete reaction mixture showed an absorbancy of 0.103 at $500 \mathrm{~nm} / \mathrm{min}$.

\begin{tabular}{lc}
\hline \multicolumn{1}{c}{ Omissions } & $\begin{array}{c}\text { Pyruvate dehydrogenase } \\
\text { activity }(\%)\end{array}$ \\
\hline None & 100 \\
Pyruvate & 6.1 \\
NAD & 19.8 \\
Coenzyme A & 0.0 \\
Thiamine pyrophosphate & 7.6 \\
$\mathrm{MgCl}_{2}$ & 105 \\
Enzyme & 0.0 \\
\hline
\end{tabular}

$13 \mathrm{nmol} / \mathrm{min} / \mathrm{mg}$ protein, respectively. These values were nearly equal to that of parent No. 1-231, and also to those of FA1-30 and 15-8. Since both strains, No. 22 and 2-11, grew slowly on medium 33, as described above, their auxotrophy was investigated. The results indicated that they required homoserine or methionine plus threonine for their growth, and they were found to be completely defective in homoserine dehydrogenase (HD). On the other hand, parent strain No. 1-231 showed low but signif-

Table IV. Specific Activities of Various EnZymes of Lysine-Producing Mutants AND Their Parents

\begin{tabular}{|c|c|c|c|c|c|c|c|c|c|c|}
\hline \multirow{3}{*}{$\begin{array}{c}\text { Strain } \\
\text { No. }\end{array}$} & \multirow{3}{*}{$\begin{array}{l}\text { Property } \\
\text { for } \\
\text { selection }\end{array}$} & \multirow{3}{*}{$\begin{array}{c}\text { Lysine } \\
\text { HCl }^{a} \\
\text { produced } \\
\text { (g/liter) }\end{array}$} & \multicolumn{8}{|c|}{ Enzyme activity (nmol $/ \mathrm{min} / \mathrm{mg}$ protein) } \\
\hline & & & \multirow[t]{2}{*}{ PD } & \multirow[t]{2}{*}{ PK } & \multirow[t]{2}{*}{$\mathrm{CS}$} & \multicolumn{2}{|c|}{$\mathrm{PC}$} & \multicolumn{2}{|c|}{ AK } & \multirow[t]{2}{*}{ HD } \\
\hline & & & & & & & $\begin{array}{l}\text { Inhibition } \\
(\%)^{b}\end{array}$ & & $\begin{array}{l}\text { Inhibition } \\
(\%)^{c}\end{array}$ & \\
\hline 2247 & (Wild) & 0.5 & 20 & 649 & 80 & 105 & 99 & 1.7 & 75 & 0.90 \\
\hline FAl-30 & $\mathrm{AEC}^{\mathrm{r}}$ & 15 & 13 & 651 & 70 & 146 & 94 & 3.5 & 8 & 0.85 \\
\hline H1013 & $\mathrm{Hse}^{-}$ & 34 & 21 & 303 & 65 & 128 & 100 & 1.8 & 73 & 0.00 \\
\hline S-20 & $\mathrm{Met}^{\mathrm{s}}$ & 25 & 48 & 798 & 111 & 145 & 93 & () & ( ) & 0.05 \\
\hline $15-8$ & $\mathrm{Glu}^{+}$ & 1 & 12 & 682 & 0.5 & 165 & 40 & 3.5 & 86 & 0.75 \\
\hline $2-190$ & $\mathrm{AEC}^{\mathrm{r}}$ & 28 & 32 & 876 & 1.6 & 206 & 45 & 1.2 & 3 & 0.43 \\
\hline $1-231$ & $\mathrm{AEC}^{\mathrm{r}}$ & 41 & 11 & 64 & 0.7 & 146 & 45 & 2.8 & 87 & 0.04 \\
\hline 22 & FPs & 51 & 11 & 77 & 0.5 & 85 & 25 & 2.7 & 76 & 0.00 \\
\hline $2-11$ & FPs & 51 & 13 & 78 & 0.4 & 152 & 32 & 2.9 & 68 & 0.00 \\
\hline $2-396$ & Met $^{\mathrm{s}}$ & 27 & 35 & 724 & 1.4 & 118 & 39 & 2.7 & 79 & 0.05 \\
\hline H3-4 & $\mathrm{Hse}^{-}$ & 33 & 50 & 1150 & 1.4 & 340 & 55 & 2.5 & 100 & 0.00 \\
\hline
\end{tabular}

a No. 22 was cultured in medium 33 supplemented with $10 \mathrm{~g} /$ liter of yeast extract. All the other strains were cultured in medium 33 supplemented with $5 \mathrm{~g} /$ liter of yeast extract.

$b \quad$ Inhibition by $10 \mathrm{~mm}$ L-aspartic acid.

c Inhibition by $1 \mathrm{~mm}$ L-lysine plus $1 \mathrm{~mm}$ L-threonine.

( ) Indicates "no examination." 


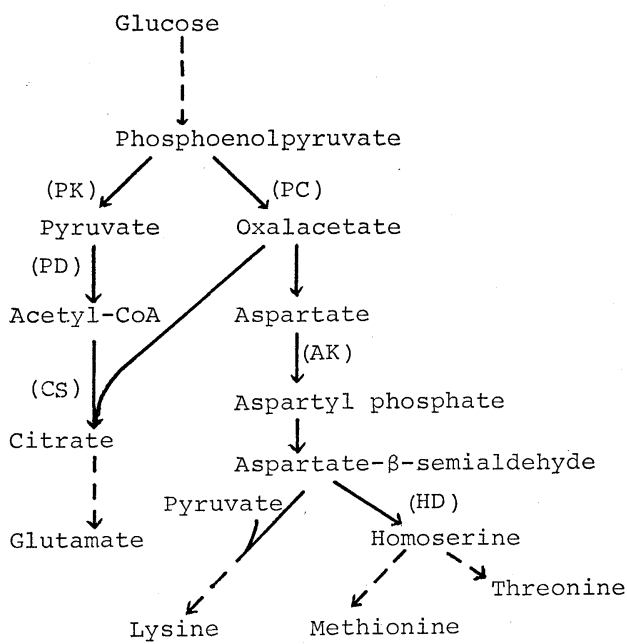

FIG. 2. The Various Enzymes Related to Lysine Biosynthesis.

PK, pyruvate kinase; PC, phosphoenolpyruvate carboxylase; PD, pyruvate dehydrogenase; CS, citrate synthase; AK, aspartokinase; HD, homoserine dehydrogenase.

icant HD activity. In the previous paper $^{6)}$ it was reported that a mutant (S-20), of which the HD activity was depressed to about $1 / 30$ of that of parent No. 2247, produced $19 \mathrm{~g} /$ liter of lysine $\cdot \mathrm{HCl}^{\mathrm{s})}$ which is $15 \mathrm{~g} /$ liter less than that of HD-defective strain H1013. Therefore the increase in the lysine productivity of mutants No. 22 and 2-11 seems to be due to their being completely defective in HD.

As parent No. 1-231 has been obtained as an AEC-resistant mutant ${ }^{11}$, it has been considered that it becomes a lysine producer as the result of desensitization of aspartokinase (AK) to feedback inhibition by lysine plus threonine like an AEC-resistant strain, FA1-30, ${ }^{4}$ which wad derived from wild strain No. 2247, but as described above, the HD activity level of No. 1-231 was found to be considerably lowered, suggesting the possibility that it becomes a lysine producer as the result of the HD depression, not AK desensitization.

\section{Various enzyme activities of lysine-producing strains}

Activities and sensitivities to feedback inhibition of enzymes related to aspartic acid and lysine biosyntheses were investigated with No. 15-8, AEC-resistant-lysine-producing strains No. 1-231 and 2-190, ${ }^{1)}$ methionine sensitivelysin producing strain No. 2-396, ${ }^{1)}$ and homoserine auxotroph H3-4, which were all derived from No. 15-8. As shown in Table IV, AK of No. 2-190 was not inhibited by $1 \mathrm{~mm}$ lysine plus $1 \mathrm{~mm}$ threonine like FA1-30, whereas AK of No. 1-231 showed inhibition of nearly the same extent as that of wild strain No. 2247 and parent strain No 15-8. On the other hand, the HD level of No. 2-190, in contrast with No. 1-231, was almost the same as that of parent No. 15-8. Phosphoenolpyruvate carboxylase (PC) of wild strain No. 2247 has been known to be inhibited by aspartic acid, ${ }^{10)}$ a substrate of AK. Phosphoenolpyruvate carboxylases of both AEC-resistant strains were found to be less sensitive to the feedback inhibitor, aspartic acid, than that of the wild strain. Low sensitivity was also observed for PC of their parent, No. 15-8, but not for its parent, No. 214-1, as shown in Table $\mathrm{V}$, suggesting that No. 15-8 got the character when it was derived ${ }^{14)}$ as a prototrophic revertant from CS-defectiveglutamate auxotroph No. 214-1. From these

\section{Table V. Enzymatic Alterations During Derivation of Strain No. 15-8 From B. flavum No. 2247}

The bacterial strains were cultured in medium 9 for $26 \mathrm{hr}$. The crude enzymes were prepared as described in Materials AND Methods. For the citrate synthase (CS) assay, $0.10,0.22$ and $0.28 \mathrm{mg}$ protein of the crude enzymes of No. 2247, 214-1 and 15-8, respectively, were added to the reaction mixture (final $1 \mathrm{ml}$ ). PEP carboxylase (PC) was assayed in the volume of absence or presence of $10 \mathrm{mM} \mathrm{L}$-aspartic acid in a reaction mixture (final volume of $1 \mathrm{ml}$ ) containing $0.10,0.11$ and $0.14 \mathrm{mg}$ protein of the crude 2247, 214 and 15-8, respectively.enzymes of No.

\begin{tabular}{|c|c|c|c|c|c|}
\hline \multirow[t]{2}{*}{$\begin{array}{l}\text { Strain } \\
\text { No. }\end{array}$} & \multirow[t]{2}{*}{$\begin{array}{l}\text { Requirement of } \\
\text { glutamate }\end{array}$} & \multicolumn{2}{|c|}{$\begin{array}{c}\text { Enzyme } \\
\text { activities } \\
\text { (nmol/min/ } \\
\text { mg protein) }\end{array}$} & \multirow{2}{*}{\multicolumn{2}{|c|}{$\begin{array}{c}\text { Inhibition } \\
\text { of PC by } \\
\text { aspartate } \\
(\%)\end{array}$}} \\
\hline & & CS & PC & & \\
\hline 2247 & No & 115 & 90 & 100 & $100^{a}$ \\
\hline $214-1$ & Yes & 0.8 & 107 & 90 & \\
\hline $15-8$ & No & 2 & 113 & 52 & $25^{a}$ \\
\hline
\end{tabular}



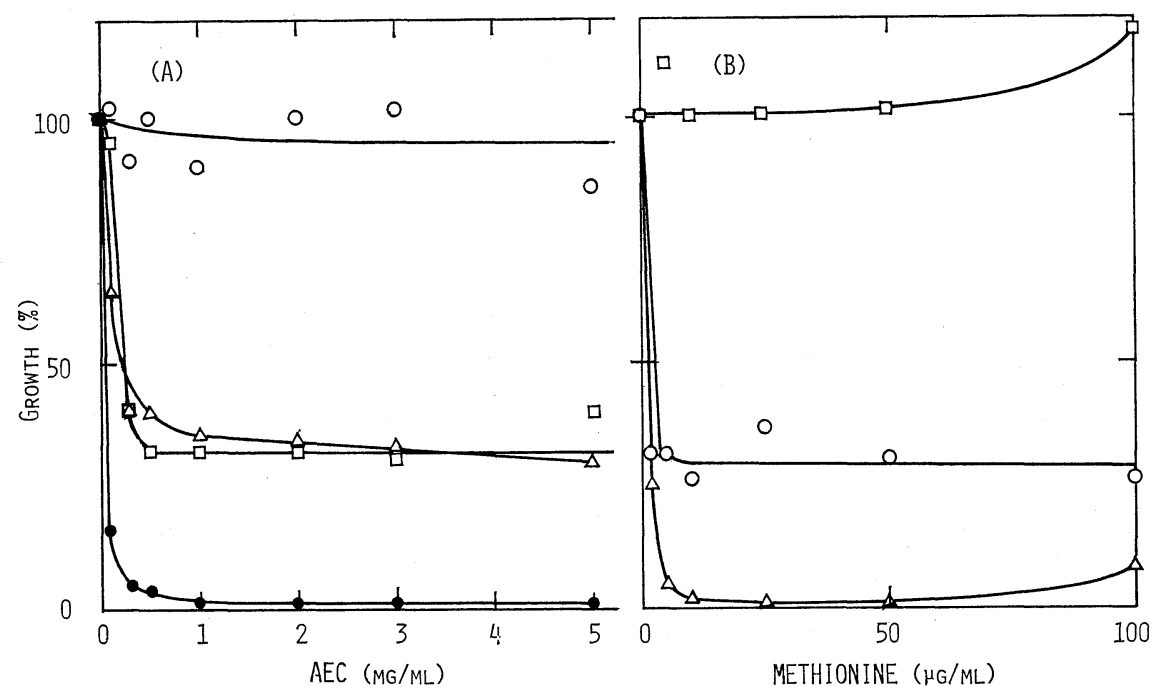

FIG. 3. Effects of AEC and Methionine on the Growth of Lysine-producing Mutants and Their Parents.

For the AEC-resistance test (A), No. $2247(\bullet), 15-8(\square), 1-231(\bigcirc)$ and 2-396 $(\triangle)$ were cultured aerobically in test tubes containing $4 \mathrm{ml}$ of medium 13 supplemented with $0.5 \mathrm{ml} /$ liter of L-methionine and $0.5 \mathrm{mg} /$ liter of L-threonine at $30^{\circ} \mathrm{C}$ for $17 \mathrm{hr}$. The cells were collected by centrifugation and resuspended in the same medium. The suspensions were inoculated to give about $10^{7}$ cells $/ \mathrm{ml}$ into medium 13 supplemented with $5 \mathrm{mg} / \mathrm{ml}$ of L-methionine and $5 \mathrm{mg} / \mathrm{ml}$ of L-threonine containing the indicated concentrations of AEC and cultured for $44 \mathrm{hr}$. The relative values for growth were calculated with the growth of each strain in the absence of AEC taken as 100.

For the methionine-sensitivity test (B), No. 15-8 ( $\square$ ), 1-231 $(\bigcirc)$ and 2-396 $(\triangle)$ were cultured as above except that methionine and threonine were not added. The culture broth $(0.03 \sim 0.05 \mathrm{ml})$ was inoculated give about $10^{7}$ cells $/ \mathrm{ml}$ into $4 \mathrm{ml}$ of medium 13 containing the indicated concentrations of L-methionine and cultured for $18 \mathrm{hr}$ for No. 15-8 or $42 \mathrm{hr}$ for No. 1-231 and 2-396.

results, the glutamate-non-auxotrophy of No. 15-8 in spite of its low CS level is probably due to the sufficient supply of glutamate for growth as the result of the increase in oxalacetate level in the cells due to desensitization of PC to aspartate inhibition. Therefore, the increase in aspartate production by No. 15-8 also appears to be due to this desensitization. Activity of pyruvate kinase (PK), another enzyme acting on phosphoenolpyruvate at the branch point in glucose metabolism, was determined. The results are also shown in Table IV. The PK level of No. 1-231 was found to be lowered to nearly one-tenth of that of parent No. 15-8. Therefore, the result indicates that both the levels of HD and PK decreased simultaneously upon mutation of No. $15-8$ to No. 1-231. On the other hand, No. 2-190, me- thionine-sensitive strain No. 2-396 and homoserine auxotroph H3-4 showed normal PK levels.

\section{Growth responses to AEC and methionine}

In spite of the result that strain No. 1-231 was obtained as an AEC-resistant strain, its AK was still sensitive to the lysine-plusthreonine inhibition as shown in Table IV. Then, it was cultured in a liquid medium containing AEC in order to confirm its AECresistance. As shown in Fig 3A, growth of No. 1-231 was inhibited only slightly by $1 \sim$ $5 \mathrm{mg} / \mathrm{ml}$ of AEC (less than $15 \%$ ), whereas that of No. 2-396 was inhibited to the same extent as parent No. 15-8. Figure 3A also shows that No. $15-8$ is slightly more resistant to AEC than wild strain No. 2247. 
Methionine-sensitivity was tested for strain No. 1-231, because its HD level was depressed to the same extent as S-20, as shown in Table IV. The growth of No. 1-231 was markedly inhibited (about $70 \%$ ) by $1 \sim 100 \mathrm{mg} /$ liter of $\mathrm{L}$ methionine as shown in Fig. 3B. The figure also shows that growth of No. 2-396 was inhibited more than $90 \%$ by $5 \sim 100 \mathrm{mg} /$ liter of the amino acid. Thus No. 1-231 was confirmed to be an AEC-resistant and methionine-sensitive mutant.

\section{DISCUSSION}

Three types of lysine-producing strains have been reported so far: that is, an HD or homoserine kinase defective homoserine or threonine auxotroph, respectively, ${ }^{5)}$ a threonine or methionine-sensitive- low-HD strain, ${ }^{6}$ and an AEC-resistant strain having feedback-insensitive AK. ${ }^{4}$ Among the AEC-resistant strains derived from No. 15-8 in the previous study ${ }^{1)}$, No. 2-190 showed feedback-insensitive AK as expected, indicating the third type of lysine producing strain. On the other hand, No. 1-231 and 2-396 showed normal AK but low levels of HD. Both the last two strains showed methionine-sensitivity, indicating the second type of lysine producing strain.

Since only No. 1-231 of the two strains showed AEC-resistance and a low PK level, the two properties seem to be related to each other. A decrease in PK level leads phosphoenolpyruvate, a metabolic intermediate of glucose, to convert more to oxalacetate, and therefore to aspartate, resulting in overcoming of the competitive feedback inhibition of $\mathrm{AK}$ by lysine plus threonine. ${ }^{11)}$ This probably causes the mutant to be AEC-resistant and the increase in the lysine production. Elevation of aspartic acid level by low PK mutants was inferred from the fact that low PK strain No. 1231 and 22 accumulated more aspartate in the medium than the normal PK strain (Table II).

The FP-sensitive strain obtained in this study showed a normal PD level unlike the strain reported previously, and was defective in HD completely. $\beta$-Fluoropyruvate has been con- sidered as a competitive inhibitor of $\mathrm{PD}$ with respect to pyruvate. Therefore FP-sensitive growth must be caused by depression of the pyruvate level as well as that of the PD level. The parent strain, No. 1-231, showed PC less sensitive to feedback inhibition and a low PK level, suggesting a much lower level of pyruvate than that of wild strain No. 2247. This might be supported by the fact that accumulation in the culture medium of alanine, valine and isoleucine which are formed through pyruvate was decreased (Table II). Less accumulation of these amino acids by FP-sensitive strain No. 22 suggests a much lower level of pyruvate which might be caused by increased lysine production (which consumes pyruvate) (Fig. 2) due to the HD defect.

Regarding lysine production, No. 22 and 211 produced $51 \mathrm{~g} /$ liter of lysine $\cdot \mathrm{HCl}$ which is $10 \mathrm{~g}$ /liter more than that produced by parent No. 1-231. The difference is in good agreement with the previous result that there is a difference of about $15 \mathrm{~g} /$ liter of lysine $\cdot \mathrm{HCl}$ production between methionine sensitive strain S-20 and HD-defective strain H1013. On the other hand, No. 22 and 2-11 produced $17 \mathrm{~g} /$ liter of lysine $\mathrm{HCl}$ more than $\mathrm{H} 1013$. This great difference is ascribed to the additional properties of low PK, low CS and feedback-less sensitive PC. These properties might also cause the much greater lysine production by No. 1-231 than that by methionine-sensitive strain S-20, which was derived directly from the wild strain. However, methionine-sensitive strain No. 2396 and HD-defective strain H3-4 both of which showed low CS and feedback-less sensitive PC, produced almost the same amount of lysine as S-20 and H1013, respectively. From these results it is reasonable to conclude that such high lysine productivities of No. 1-231, 22 and 2-11 are due to the low PK level.

In the AEC-resistant strains with feedbackinsensitive AK and normal HD levels, depression of the CS level and desensitization of PC to the feedback inhibition caused an increase in the lysine production from $15 \mathrm{~g} /$ liter (by FA1-30) to $28 \mathrm{~g} /$ liter (by 2-190) as reported in the previous paper. ${ }^{1)}$ 
Acknowledgments. The authors are indebted to Dr. T. Akashi and Dr. Y. Hirose of the Central Research Laboratories for their encouragement during this work.

\section{REFERENCES}

1) I. Shiio, H. Ozaki and K. Ujigawa-Takeda, Agric. Biol. Chem., 46, 101 (1982).

2) O. Tosaka, H. Morioka and K. Takinami, Abstract of Papers, General Meeting of Agric. Biol. Chem. Soc. of Japan, 1978, p. 176.

3) I. Shiio and K. Ujigawa, J. Biochem., 84, 647 (1978).

4) K. Sano and I. Shiio, J. Gen. Appl. Microbiol., 16, 373 (1970).

5) K. Sano and I. Shiio, J. Gen. Appl. Microbiol., 13,
349 (1967).

6) I. Shiio and K. Sano, J. Gen. Appl. Microbiol., 15, 399 (1969).

7) F. D. Chinard, J. Biol. Chem., 199, 91 (1952).

8) L. M. Hinman and J. P. Blass, J. Biol. Chem., 256, 6583 (1981).

9) I. Shiio, H. Ozaki and K. Ujigawa, J. Biochem. 82, 395 (1977).

10) H. Ozaki and I. Shiio, J. Biochem., 66, 297 (1969).

11) I. Shiio and R. Miyajima, J. Biochem., 65, 849 (1969).

12) R. Miyajima, S. Otsuka and I. Shiio, J. Biochem., 63, 139 (1968).

13) O. H. Lowry, N. J. Rosebrough, A. L. Farr and R. J. Randall, J. Biol. Chem., 193, 265 (1951).

14) I. Shiio and K. Ujigawa-Takeda, Agric. Biol. Chem., 43, 2479 (1979). 